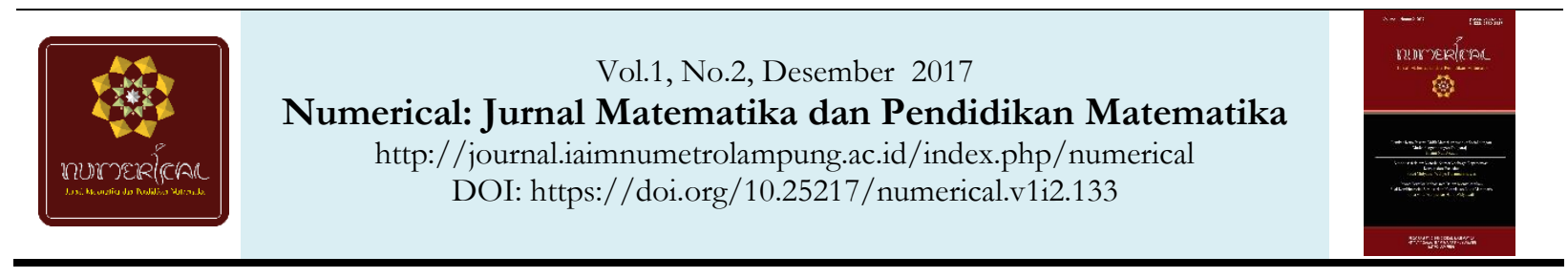

\title{
Pengembangan Desain Didaktis Bahan Ajar Materi Pemfaktoran Bentuk Aljabar pada Pembelajaran Matematika SMP
}

\author{
Nurwani ${ }^{1}$, Rizki Wahyu Yunian Putra ${ }^{2}$, Fredi Ganda Putra ${ }^{3}$, Nugraha Wisnu Putra ${ }^{4}$
}

1,2,3 Universitas Islam Negeri Raden Intan Lampung, Indonesia

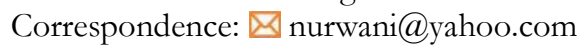

\begin{tabular}{|c|c|}
\hline Article Info & Abstract \\
\hline Article History & The ability to understand a concept in the learning of mathematics is something that \\
\hline Received : 06-09-2017 & is required by each learner. But in fact show that in the learning process, teaching \\
\hline Revised : 17-10-2017 & materials used have not trained learners in doing a discoverv and learners less active \\
\hline Accepted : 19-10-2017 & in the learning process. This study aims to produce teaching materials in the form of \\
\hline Keywords: & a didactic design module teaching materials Algebra on Mathematics Subjects for \\
\hline $\begin{array}{l}\text { Algebra; Didaktis; } \\
\text { Development. }\end{array}$ & $\begin{array}{l}\text { Class VIII Semester } 1 \text { Subject material Algebra in SMP Negeri } 1 \text { Pakuan Ratu. The } \\
\text { teaching materials module with didactic design is a module in the form of a learner's } \\
\text { guide which contains information, materials about Algebra, examples of problems as } \\
\text { well as exercise questions, in accordance with the problems that natural learners on } \\
\text { learning materials, this instructional material is made to petrify participants educated } \\
\text { in solving problems on Algebra material. Based on the results of research, Didactic } \\
\text { instructional materials developed by researchers deserve to be used according to the } \\
\text { validation results of material experts, linguists, education practitioners, media } \\
\text { experts, and help learners to learn more independently and comfortable in the } \\
\text { learning process as well as learners are very interested in teaching materials } \\
\text { (modules) of this didactic design. }\end{array}$ \\
\hline
\end{tabular}

\section{PENDAHULUAN}

Matematika adalah sebagai suatu bidang ilmu yang merupakan alat pikir, berkomunikasi, alat untuk memecahkan sebagai persoalan praktis, yang unsur-unsurnya logika dan intuisi analisa dan konstruksi, generalitas dan individualitas, serta mempunyai cabang-cabang antara lain aritmatika, aljabar, geometri, dan analisis [1]. Untuk itu, matematika perlu diberikan sejak dini kepada peserta didik [2]. Dalam dunia pendidikan, matematika merupakan mata pelajaran yang menjadi salah satu unsur penting dalam perkembangan ilmu pengetahuan dan teknologi [3]. Dengan demikian peserta didik yang terbiasa berpikir secara matematik akan lebih mudah berpikir logis dan rasional. Selain itu matematika termasuk salah satu pelajaran wajib yang diberikan untuk peserta didik SD, SMP, dan SMA yang juga termasuk dalam mata pelajaran ujian nasional, dengan demikian peserta didik harus mampu menguasai pelajaran matematika. Namun kenyataannya, prestasi matematika peserta didik masih rendah. Argument ini diperkuat dengan laporan dari the Internasional Mathematics and Science Study (TIMSS) tahun 2011 tentang prestasi matematika dan sains peserta didik SMP kelas VIII yang menurun, dengan skor rata-rata yaitu 400. Padahal, TIMSS tahun 1999, 2013 dan 2007 skor rata-rata yang diraih Indonesia secara berturutturut adalah 403, 411 dan 405 dengan skor rata-rata internasional adalah 500 [4]. Melihat hal ini, menunjukkan bahwa secara umum matematika merupakan salah satu mata pelajaran berindeks rendah.

Berdasarkan hasil observasi yang dilakukan oleh peneliti pada tanggal 16 Agustus 2017, tampak bahwa pembelajaran matematika di SMP Negeri 1 Pakuan Ratu merupakan kegiatan yang dilaksanakan 
oleh guru, dengan mengenalkan subjek, memberi satu dua contoh, lalu menanyakan satu atau dua pertanyaan, dan pada umumnya peserta didik yang biasanya mendengarkan secara pasif diminta untuk menjadi aktif dengan mulai mengerjakan latihan yang diambil dari buku. Selanjutnya aktivitas serupa dilakukan untuk pertemuan-pertemuan berikutnya. Aktivitas yang menjadi rutinitas dimana guru menerangkan materi dan murid menerima materi [5]. Senada dengan itu Djojonegoro mengungkapkan bahwa kebanyakan sekolah dan guru-guru pada umumnya terfokus pada perolehan jawaban peserta didik yang benar dalam mengembangkan proses dan menurunkan jawaban [5].

Aktifitas pembelajaran matematika tersebut masih tergolong kepada pembelajaran konvensional, peserta didik monoton bagaimana gurunya mendemonstrasikan penyelesaian soal-soal matematika di papan tulis dan menuliskan apa yang dituliskan oleh gurunya [5]. Supaya proses pembelajaran konvesional tersebut tidak terjadi, seharusnya dalam proses pembelajaran matematika yang berlangsung guru harus bisa menciptakan situasi didaktis dan hubungan pedagogis, seperti yang diutarakan oleh Suryadi bahwa pembelajaran matematika pada dasarnya berkaitan dengan tiga hal yaitu guru, peserta didik dan matematika, antara ketiga aspek tersebut memiliki keterkaitan satu sama lain yang mempengaruhi jalannya suatu pembelajaran [6]. Oleh karena itu, hubungan guru-peserta didik, peserta didik-materi, dan guru-materi harus lebih diperhatikan sehingga ketika pembelajaran berlangsung bisa lebih baik lagi.

Kesulitan yang dihadapi peserta didik dalam belajar sebenarnya bukan akibat dari peserta didik itu sendiri, tetapi dapat saja bersumber dari cara guru dalam menyajikan materi ataupun materi ajar yang digunakan pada saat pembelajaran terjadi. Dari gagasan inilah kemudian dikemukakannya istilah learning obstacles (hambatan belajar). Gagasan tentang learning obstacles memandang bahwa kesulitan yang dialami oleh peserta didik dapat disebabkan dari beberapa sumber, diantaranya guru, materi ajar, dan peserta didik itu sendiri [7]. Oleh karena itu jika dalam desain pembelajaran yang dikembangkan guru sudah dapat mengantisipasi kemungkinan munculnya hambatan belajar, maka hasilnya tentu akan lebih baik.

Berdasarkan uraian di atas, penulis berupaya untuk mengatasi permasalahan yang ada dengan melakukan pengembangan desain didaktis bahan ajar (modul) materi aljabar pada pembelajaran matematika SMP yang melalui tiga tahap formal, yaitu analisis situasi didaktis sebelum pembelajaran berupa desain didaktis hipotetik termasuk ADP, analisis meta pedadidaktik yang merupakan tahap implementasi desain didaktis hipotetik, dan analisis retrospektif yang merupakan tahap refleksi untuk merumuskan desain didaktis empirik. Pemilihan modul ini dikarenakan penerapan modul pada proses pembelajaran dapat membuat peserta didik lebih tertarik dalam belajar [8]. Dalam penelitian ini, penulis mengembangkan desain bahan ajar berupa modul yang mencakup materi aljabar pada jenjang matematika SMP.

\section{METODE}

Jenis penelitian yang di gunakan dalam penelitian ini adalah Research and Development (R\&D). Langkah-langkah penelitian ini menggunakan sebuah metode penelitian menurut Borg and Gall yang telah dimodifikasi oleh Sugiyono [9]. Pada penelitian ini hanya dilakukan hingga tujuh langkah, karena dalam pembuatan produk hanya dibatasi pada pembuatan produk sampai dengan baik untuk digunakan saja. Penelitian ini menggunakan pendekatan kuantitatif dan kualitatif. Teknik pengumpulan data dalam penelitian pengembangan modul didaktis ini menggunakan dua jenis, yaitu wawancara dan kuisioner (angket). 
Angket validasi ahli terkait kemenarikan, penyajian, kesesuaian isi, kebahasaan dan kesesuaian media pembelajaran memiliki 4 pilihan jawaban sesuai konten pertanyaan. Masing-masing pilihan jawaban memiliki skor berbeda yang mengartikan tingkat validasi media pembelajaran.

\section{HASIL PENELITIAN DAN PEMBAHASAN}

Hasil utama dari penelitian dan pengembangan ini adalah desain didaktis bahan ajar (modul) materi aljabar. Penelitian dan pengembangan ini dilakukan dengan menggunakan prosedur pengembangan menurut sugiyono yang dilakukan dari tahap 1 hingga tahap 7. Data hasil setiap tahapan prosedur penelitian dan pengembangan yang dilakukan adalah sebagai berikut:

1. Identifikasi (learning obstacle)

Identifikasi (learning obstacle) yaitu identifikasi kesulitan belajar, untuk mengetahui kesulitan belajar peserta didik maka penulis melakukan wawancara terhadap guru matematika SMPN 1 Pakuan Ratu serta peserta didik SMPN 1 Pakuan Ratu. Selanjutnya melakukan uji soal terhadap peserta didik yang memenuhi semua komponen-komponen materi pemfaktoran bentuk aljabar kelas VIII. Dari hasil uji soal maka dapat diketahui kesulitan peserta didik pada materi Pemfaktoran bentuk aljabar di temukan masalah peserta didik kesulitan jika dalam pefaktoran bentuk aljabar nilai konstantanya $>10$ dan variabelnya kuadrat seta cara memfaktorkan jika bentuk aljabar suku tiga.

2. Pengumpulan dan Pengolahan Data

Setelah melakukan Identifikasi (learning obstacle) dan mengetahui hasilnya, dalam pengembangan ini langkah selanjutnya yaitu mengumpulkan dan mengolah data yang menunjang pengembangan bahan ajar

3. Penyusunan Desain Didaktis Bahan Ajar

Setelah dilakukan analisis kebutuhan langkah selanjutnya adalah desain produk. Ada beberapa hal yang dilakukan dalam tahap desain produk pengembangan desain didaktis bahan ajar materi pemfaktoran bentuk aljabar pada pembelajaran matematika SMP.

4. Validasi Produk

Validasi dilakukan oleh ahli materi yaitu 1 dosen UIN Raden Intan Lampung, Bapak Syazali, M.Si dan 1 guru SMPN 1 Pakuan Ratu ibu Umu Kholifah,S.pd, ahli media yaitu 1 Dosen UIN Raden Intan Lampung Bapak Abi Fadila, M.Pd, ahli bahasa 1 Dosen UIN Raden Intan Lampung Bapak Untung Novriansyah,M.Pd dan ahli praktisi pendidikan 1 dosen UIN Raden Intan Lampung, BapakSuherman, M.Pd dan 1 guru SMPN 1 Pakuan Ratu ibu Rika Sartika, S.Pd. Adapun validasi yang dilakukan oleh validator yaitu melalui 2 tahap validasi, hasil penilaian pada ahli materi mencapai kriteria interpretasi "Baik" yaitu dengan persentase rata-rata mencapai 4.428 setelah melakukan tahap revisi oleh ahli materi yaitupada penjabaran materi dan penulisan smbol-simbol matematika dalam bahan ajar. Persentase rata-rata yang dicapai oleh ahli media yaitu 4.642 dengan kriteria "Sangat Baik" setelah melakukan tahap revisi padabacground dan biografi. Persentase ratarata yang dicapai oleh praktisi pendidikan yaitu4.833dengan kriteria "Sangat Baik" setelah melakukan tahap revisi pada latihan soal dan penilaian juga dilakukan oleh ahli bahasa dengan persentase rata-rata mencapai 3.9dengan kriteria"Sangat Baik".

5. Revisi Desain Produk

Setelah desain produk divalidasi melalui penilaian ahli materi, ahli media, ahli praktisi pendidikan dan ahli bahasa serta guru MTK SMP/MTs kelas VIII, peneliti melakukan revisi terhadap desain produk yang dikembangkan berdasarkan masukan-masukan ahli tersebut. 
Numerical: Jurnal Matematika dan Pendidikan Matematika, Vol. 1 No. 2 Desember 2017, 97-102

Nurwani, Rizki Wahyu Yunian Putra, Fredi Ganda Putra, Nugraha Wisnu Putra

6. Uji Coba Produk

a. Uji coba Skala Kecil

Pada uji coba kelompok kecil dimaksudkan untuk menguji kemenarikan produk, peserta didik/i dalam uji kelompok kecil ini melihat media pembelajaran yang diberikan, dan diakhir uji coba produk dengan melibatkan 10 peserta didik.

b. Uji Coba Lapangan

Setelah melakukan uji coba kelompok kecil, kemudian produk diuji cobakan kembali ke uji coba lapangan. Uji coba lapangan ini dilakukan untuk meyakinkan data dan mengetahui kemenarikan produk secara luas. Responden pada uji kelompok besar ini berjumlah 22 peserta didik.Dari hasil uji coba media pembelajaran yang di telah dilakukan di SMPN 1 Pakuan Ratu terlihat bahwa rata- rata hasil uji coba menurun dimana pada uji coba skala kecil rata- ratanya adalah 4,3 dengan kriteria "sangat baik" dan uji coba skala besar 4,277 dengan kriteria"sangat baik". Dari hasil uji coba tersebut walaupun terlihat hasilnya menurun namun sama-sama memiliki kriteria sangat baik, jadi produk bahan ajar desain didaktis tersebut layak digunakan.

7. Revisi Produk

Setelah dilakukan uji coba kelompok kecil dan uji coba kelompok besar untuk mengetahui kemenarikan bahan ajar (modul) desain didaktis, produk dikatakan menarik,setelah melalukan revisi yang dilakukan 2 tahap oleh validator ahli materi dosen UIN Raden Intan lampung dan Guru SMP Negeri 1 Pakua Ratu, Praktisi Pendidikan dosen UIN Raden Intan lampung dan Guru SMP Negeri 1 Pakuan Ratu Ahli media Dosen UIN Raden Intan Lampung, Ahli Bahasa 1 Dosen UIN Raden Intan Lampung, pada penelitian ini tahap revisi adalah tahap terakhir. Media pembelajaran yang telah direvisi akan menjadi media pembelajaran yang telah memenuhi standar kemenarikan media pembelajaran yang ditinjau dari sisi materi, praktisi pendidikan, bahasa dan media. Sehingga dihasilkan desain didaktis bahan ajar (modul) materi aljabar pada pembelajaran Matematika SMP.

\section{SIMPULAN DAN SARAN}

Berdasarkan hasil penelitian, Bahan ajar (modul) desain didaktis yang dikembangkan oleh peneliti layak digunakan menurut hasil validasi dari ahli materi, ahli bahasa, ahli praktisi pendidikan, ahli media, dan membantu peserta didik untuk belajar lebih mandiri dan nyaman dalam proses belajar serta peserta didik sangat tertarik dengan bahan ajar (modul) desain didaktis ini. Saran bagi para peneliti berikutnya adalah agar melanjutkan oenelitian ke tahap eksperimen modul ini untuk melihat kualitas dari modul ini sendiri.

\section{DAFTAR PUSTAKA}

[1] Uno, H. B., Model Pembelajaran Menciptakan Proses Belajar Mengajar Yang Kreatif dan Efektif. Jakarta: Bumi Aksara, 2011.

[2] Santi Widyawati, Mardiyana, and Gatut Iswahyudi, "Eksperimentasi Model Pembelajaran Kooperatif Tipe Two Stay Two Stray (TSTS) dan Numbered Heads Together (NHT) Ditinjau dari Kecerdasan Majemuk Peserta Didik," J. Elektron. Pembelajaran Mat., vol. 2, no. 9, pp. 972-983, 2014. 
[3] Wulandari, P., Mujib, and Putra, F. G., "Pengaruh Model Pembelajaran Investigasi Kelompok berbantuan Perangkat Lunak Maple terhadap Kemampuan Pemecahan Masalah Matematis," AlJabar J. Pendidik. Mat., vol. 7, no. 1, pp. 101-106, 2016.

[4] Tim Puspendik, Final Report Determinants Of Learning Outcomes TIMSS 2011. Jakarta: Pusat Penilaian Pendidikan Badan Penelitian dan Pengembangan Kementrian dan Kebudayaan, 2011.

[5] Turmudi, Pembelajaran Matematika Kini dan Kecenderungan Masa Mendatang. Bandung: JICA-FPMIPA, 2010.

[6] Suryadi, D., "Penelitian Pembelajaran Matematika Untuk Pembentukan Karakter Bangsa,” 2010. .

[7] Palpialy, J. J., "Pengembangan Desain Didaktis Materi Pecahan pada Sekolah Menengah Pertama (SMP)," Doctoral Dissertation, Universitas Pendidikan Indonesia, Bandung, 2016.

[8] Peniati, E., "Pengembangan Modul Mata Kuliah Strategi Belajar Mengajar IPA Berbasis Hasil Penelitian Pembelajaran," J. Pendidik. IP A Indones., vol. 1, no. 1, 2012.

[9] Sugiyono, Metode Penelitian Kuantitatif, Kualitatif dan R\&D. Bandung: Alfabeta, 2015.

[10] Novitasari, S. A. and Dewa, PNI., "Pengembangan Lembar Kerja Peserta didik (LKS) untuk Mengoptimalkan Praktikum Virtual Laboratorium Materi Induksi Elektromagnetik," J. Pembelajaran Fis., vol. 1, no. 3, pp. 255-265, 2013. 
Numerical: Jurnal Matematika dan Pendidikan Matematika, Vol. 1 No. 2 Desember 2017, 97-102

Nurwani, Rizki Wahyu Yunian Putra, Fredi Ganda Putra, Nugraha Wisnu Putra

[Halaman ini sengaja dikosongkan] 